\title{
Public buffer stocks as agricultural output price stabilization policy in Ghana
}

\author{
Emmanuel Abokyi ${ }^{1,2^{*}}$, Henk Folmer $^{2,3}$ and Kofi Fred Asiedu ${ }^{1}$
}

\begin{abstract}
Background: Food price volatility poses widespread risks, from farmers to consumers, notably in developing countries. Because of its devastating effects on sustainable farming and food security, particularly for the poor, it continues to be a crucial policy priority. Governments have applied various methods of stabilizing domestic food prices including publicly held buffer stocks, import and export tariffs and production supports. This study evaluates Ghana's agricultural output price stabilization policy implemented in the context of the National Buffer Stock Program.

Results: Based on data from the Ministry of Food and Agriculture, we apply the coefficient of variation and the corrected coefficient of variation to analyze the volatility of output prices of maize and rice. The results show that the price volatility of maize and rice has declined in the markets where the policy has been implemented but not in the non-policy markets.
\end{abstract}

Conclusion: There is, therefore, empirical evidence that the policy has been successful.

Keywords: Agricultural output, Price volatility, Price stabilization policy, Buffer stock, Coefficient of variation, Augmented Dicky-Fuller test, Ghana

\section{Background}

Surges in global food prices continue to be of serious concern to governments all over the world, especially in developing countries, because of the devastating effects it has on food security for the poor and on sustainable production of agricultural commodities [1]. When food price levels increase, household purchasing power is lowered, especially for the poor [2]. However, farmers are often delighted with increases in price levels for their farm products with the expectation that it provides them with higher income [3]. The opposite holds when prices fall. While consumers prefer low and producers high price levels, volatility-magnitude and direction-ultimately results in harmful effects on both producers and consumers [4]. High food price volatility, therefore, is very detrimental to every country because it can cause serious political, economic and social problems [5].

\footnotetext{
*Correspondence: eabokyi@gimpa.edu.gh; eabokyi@yahoo.com ${ }^{1}$ GIMPA Consultancy, Training and Innovation Directorate (GCTID), Ghana Institute of Management and Public Administration, Accra, Ghana
} Full list of author information is available at the end of the article
Price volatility in agricultural commodity markets is normal [6]. According to Prakash [7], it is natural and instrumental that, when there is a shortage in the supply of a particular agricultural commodity, its price will increase, consumption will decline, and investment in the production of the commodity is stimulated. Therefore, some level of volatility is needed for commodity markets to function well [8]. However, it becomes of much concern when the magnitude and the frequency of the volatility are such that producers and consumers find it difficult to cope with them. Sumpsi [9] demonstrates that agricultural commodity volatility has negative impacts on food security and health. For example, when food prices rise sharply, households are likely to respond by eating cheaper and less nutritious foods, which can have potential lifelong effects on the social, physical, and mental well-being of millions of people. When children are malnourished, it exposes them to the risk of stunting, underweight, morbidity and mortality. In developing countries, the risk posed by high food price volatility is precarious for poor households because they spend a substantial proportion of their income on food, and hence price volatility poses a very high risk to them. For instance, in 
Sub-Saharan Africa, poor households spend about $60 \%$ of their income on food [8]. The nature and magnitudes of the effects that food price volatility poses in developing countries vary depending inter alia on the specific country poverty levels $[10,11]$.

Food price volatility also poses the risk of unsustainable farming because of under- or deinvestment. High levels of volatility in food prices deter smallholder farmers-who are often risk averse-from making the necessary investments to increase productivity and production [3]. Furthermore, banks and other financial institutions tend to shy away from giving loans to farmers due to high financial risks and default. Consequently, adoption of efficient technologies will be low which has consequences for agricultural modernization, irrigation, and good agricultural practices. The effect is low productivity and poor income levels for farmers [12] which ultimately may have consequences for economic growth.

Low prices for agricultural commodities and food price volatility can be periodical [1] and thus reduce farmer's household income during periods of glut or harvest time. This is especially for crops for which farmers have low or no storage capacity or lack the possibility to process into other products. In such situations, rural farmers often need to sell their farm produce at harvest time which results in the underpricing of farm products and makes farmers poor [13].

Food price volatility can also lead to political instability [14]. Arezki and Brückner [15] in their study across 120 countries conclude that in low-income countries, when food prices increase, political institutions deteriorate which is likely to increase the probability of civil conflicts and other forms of civil strife, such as anti-government demonstrations and riots. Berazneva and Lee [16] found that some of the political and social unrest in Africa and Asia in 2007 and 2008 was the result of the food price crises at the time. Bellemare [17] and Schneide [18] report that rising food prices have caused political unrest across Africa, Latin America, Asia, and the Middle East.

Food price volatility may also have macroeconomic implications, particularly for imports and inflation. During periods of high food prices, countries often import food to supplement local supply which can lead to increased demand for foreign currency and consequently unfavorable exchange rates. According to Clapp [19], high volatility of food prices can result in the devaluation of the currency of a country. In Sub-Saharan Africa, this risk is aggravated by the fact that most of the countries are net importers of food.

Because of its far-reaching implications, reducing food price volatility has been a core issue in agricultural policy. According to Rashid [20], one of the most widely debated agricultural output price stabilization policy options is dual pricing implemented through buffer stock operations. The dual pricing mechanism involves the setting up of ceiling and floor prices in a commodity market, i.e., a price band, such that the government can intervene when prices are outside of the band/range [21]. Within the band, prices are allowed to fluctuate. Outside the band, the government intervenes by purchasing produce from farmers, usually during the harvesting period, at a fixed price within the band which is higher than the prevailing market price. In addition, during lean periods when prices are high, the government intervenes by selling produce to consumers at a lower price than the prevailing price such that prices (return into) are kept within the band. This policy was adopted by many Asian countries during the Green Revolution. In many African countries, stabilization of agricultural output prices through buffer stock operations tends to focus on grains because of their storability and because they constitute a large share of the food requirements of most rural and urban households.

In Indonesia, the implementation of the buffer stock operation is done by a special food and logistics agency called the Bandan Urusan Logistik (BULOG). BULOG manages a nationwide set of local agencies at the district level: the Depot Logistics (DOLOGs). The main function of the DOLOGs is to store rice for BULOG. BULOG procures paddy rice from farmers' cooperatives as well as from private traders. Individual farmers are encouraged to establish village cooperatives from which rice is purchased to lift the price in rural markets to the floor price. BULOG has also been given monopolistic power to import rice when domestic production is low and to export it when is high [22].

In Zambia, the Zambia Food Reserve Agency (FRA) was set up by the government in 1996 to stabilize grain prices. FRA, a parastatal strategic food reserve agency, buys maize at territorially determined prices that typically exceed wholesale market prices in the major maizeproducing areas during periods of glut. FRA then stores the maize and at the appropriate time, exports it or sells it domestically. Prices are determined by tender, auction, or administratively. In years when there is a deficit in production, the FRA imports maize which it sells to selected large-scale millers at prices that are below the market prices.

In India, buffer stocks are operated by a food grains management system. The government is the dominant agency in most market operations of grains, such as procurement, storage, transport, and distribution. All these activities are carried out by the Food Corporation of India (FCI), a government agency. However, the procurement price is set by another government agency, the Commission for Agricultural Costs and Prices (CACP). 
The CACP bases the price on production costs and includes a return to land and family labor.

In Ghana, the 2008 world food crisis led to food security concerns and brought to the fore persistent hunger $[23,24]$, agricultural production issues and welfare of the citizens as a result of the drastic increases in prices of some commonly traded foods such as rice, maize, and wheat which rose by $50-75 \%$ over a matter of weeks [25]. As a response, Ghana introduced its agricultural output price stabilization policy consisting of buffer stock operations and a dual pricing mechanism. The policy has been in operation for the past 8 years.

This paper seeks to provide an empirical evaluation of this policy in Ghana. The basic question it addresses is: has the volatility, highs and lows, of prices of maize and rice been reduced, following the implementation of buffer stocking and dual pricing? Accordingly, the paper shows that buffer stocking can be applied as a means to ensuring price stabilization in the agricultural food systems in Ghana. The paper presents econometric tests for the efficacy of public buffer stock operations as reflected by reduced price volatility measured by the (corrected) coefficient of variation. The intervention involves government purchasing maize and rice from farmers through agents during periods of glut at a fixed price and re-selling when prices are high.

The structure of the rest of the paper is as follow. "Ghana's agricultural output price stabilization policy" section presents a description of the agricultural output price stabilization policy implemented in Ghana. "Methods" section presents the data, methods and the empirical results. Summary and conclusions follow in "Conclusion" section.

\section{Ghana's agricultural output price stabilization policy}

During the 2007/2008 world food price crisis, the government of Ghana had to import food from the international market as domestic food prices were soaring. In response, in 2009 the current agricultural output price stabilization policy was implemented across the country. The policy seeks to stabilize the prices of two key agricultural outputs: rice and maize. The implementation of the policy saw the setting up of the National Buffer Stock Company (NAFCO). NAFCO was primarily designed to stabilize prices of cereals (maize and rice) by smallholder farmers, particularly to reduce potential annual gluts that characterize maize and rice production. NAFCO purchases excess outputs of these cereals at a fixed (floor) price set by government above the open market price during the glut period and sells them during the lean period. The aim is to insulate farmers against losses, provide them with assured income, help increase their yields and stimulate the expansion of agricultural land and inputs to improve production. It is also to provide consumers with a respite when prices of cereals are getting too high.

The determination of the floor price is done annually by the Ministry of Food and Agriculture (MoFA) through the Post-Harvest Committee. This committee is made up of representatives of farmer associations, NAFCO and MoFA. In determining the floor price, the committee takes into account the cost of production and ensures that a minimum of 15 percent or more profit margin is added. The purchase of maize and rice is made across the different maize growing areas spread across five regions in the country with potential spatial differentials in the cost of production. However, the committee does not take into account local price differentials when setting the floor price [26]. The determination of the ceiling price is done by NAFCO taking into consideration the prevailing open market price. The purchase of the cereals is done by Licensed Buying Agents (LBCs) which are private companies. The LBCs purchase the cereals on behalf of NAFCO at the floor price determined by the Post-Harvest Committee on a commission basis in the various rural communities. For every $100 \mathrm{~kg}$ bag of maize purchased from farmers by LBCs and delivered to the NAFCO warehouse, NAFCO pays a percentage of the fixed price to the LBCs as a commission. The percentage of the commission is determined by taking into consideration the distance of the location where the maize was purchased from.

Storage of the cereals is done by NAFCO with the use of the GrainPro Cocoon technology. GrainPro Cocoons are airtight unsupported rectangular structures made of lightweight UV-resistant PVC. The simple two-piece Cocoon consists of a top cover, and a floor piece joined with a PVC tongue and groove zipper similar to those used to close environmental safety suits. Insects trapped in the bagged grain expire in a matter of days as a result of an increase in carbon dioxide and reduction of oxygen. Cocoons are packed folded in a carry bag for transport and can be made ready for use in minutes. The technology can store bagged agricultural outputs such as grains, seeds, cocoa and coffee beans, and others.

Farm price volatility is the extent to which prices of farm produce rise or fall beyond the expectations of consumers and farmers [27]. In other words, it is the unpredictable change in price [28] defined over a specific period [29]. Von Braun and Tadesse [30] define price volatility as the deviation of a price series from its mean. This study focuses on two key agricultural outputs: maize and rice. The methods we adopt in measuring the output price volatility are the coefficient of variation and the corrected coefficient of variation. 


\section{Methods}

\section{The ADF test}

The data analyzed are real monthly wholesale prices for maize and rice reported by the Ministry of Food and Agriculture of Ghana. In preparation for the analyses, we tested each series for the presence of a unit root using the augmented Dickey-Fuller (ADF) test [31]. The ADF test is specified as:

$$
\begin{aligned}
\Delta y_{t}= & \alpha+\beta y_{t-1}+\delta t+\zeta_{1} \Delta y_{t-1} \\
& +\zeta_{1} \Delta y_{t-2} \cdots+\zeta_{k} \Delta y \zeta_{t-k}+\varepsilon_{t}
\end{aligned}
$$

where $y$ is price, $t$ is time, $k$ is the number of lags, $\beta$ and $\delta$ are unknown parameters. Since the price series are monthly data, we used $k=12$ lags [32] with a time trend.

The main hypothesis of interest is $\mathrm{H}_{0}: \beta=0$ versus $\mathrm{H}_{1}$ : $\beta<0$. Failure to reject $\mathrm{H}_{0}$ indicates that the data series have a unit root and ought to be differenced. The test is one sided. The asymptotic distribution of the usual $t$ statistic under $\mathrm{H}_{0}$ is the augmented Dicky-Fuller distribution with critical values tabulated by Dicky and Fuller [31], Banerjee et al. [33], Cheung and Pascual [34] among others.

When the data are non-stationary, we follow Yang et al. [35] and use the difference of the logarithm of the prices to generate log price series. The log-differenced series is/ are:

$$
P R_{t}=\ln \left(P_{t}\right)-\ln \left(P_{t-1}\right)
$$

where $\mathrm{PR}_{\mathrm{t}}$ is the log-differenced series of the price series. With the log series, the CV is estimated in percentages.

\section{Coefficient of variation (CV) and the corrected coefficient of variation (CCV)}

Common approaches to measuring price volatility of agricultural outputs or food are the standard deviation and the coefficient of variation (CV) $[36,37]$. The $\mathrm{CV}$ is the ratio of the standard deviation to the mean defined as [38]:

$$
\mathrm{CV}=\frac{\text { standard deviation }}{\text { mean }}=\frac{\sqrt{\frac{\sum_{i=1}^{n}\left(P_{t}-\bar{P}\right)^{2}}{n}}}{\bar{P}}
$$

where $\bar{P}$ is the mean of the (in the present case, price) series $P_{t}$, and $n$ is the number of observations or data points.

The CV is a unit-free measure of variability [39] and is expressed as a percentage. It is applied in many disciplines [40]. The CV is also used to compare the variability of two series. Particularly, let period 1 be the policy-off period and period 2 the policy-on period. The hypothesis to be tested is $C_{1}=C_{2}$ against-in the present case study - the alternative $\mathrm{CV}_{1}>\mathrm{CV}_{2}$, i.e., the $\mathrm{CV}$ for the policy-off period (market without buffer stock policy) is greater than the $\mathrm{CV}$ for the policy-on period (market with buffer stock policy).

The test statistic $Z$ is [41]:

$$
Z=\frac{a\left(\frac{S_{1}}{\bar{P}_{1}}-\frac{S_{2}}{\bar{P}_{2}}\right)}{\left[\frac{2}{n}\left(\frac{\gamma_{1}^{2}}{2}+\gamma_{2}^{2}\right)\right]^{1 / 2}}
$$

where $\alpha=\sqrt{(n /(n-1)}$ with $\mathrm{n}$ the number of observations, $S_{1}$ and $S_{2}$ the standard deviations of price series 1 and 2 , respectively, $\bar{P}_{1}$ and $\bar{P}_{2}$ their means, and $\gamma_{1}^{2}$ and $\gamma_{2}^{2}$ their variances. When the number of observation between the series is different, $\mathrm{n}$ is the average number of observations of the two series. The $Z$-statistic follows the standard normal distribution. Although we expect a dampening policy effect on price volatility, we nevertheless apply a two-sided test.

Although the CV is widely used, its ability to fully capture price volatility is limited as it assumes that the variance of the price series is constant over time [42]. This particularly so, if there is non-stationarity due to a unit root or random-walk behavior, then the use of the CV can lead to over-estimation of volatility. There are two options to overcome the non-stationarity issue: removing it by differencing, as outlined above, or by applying the corrected coefficient of variation $(\mathrm{CCV})$ to the non-stationary data. The CCV, also called the Cuddy-Della Valle instability index [43-45], is a transformation of the CV. Bediane and Odjo [46] described the CCV as the trendcorrected CV. According to Huchet-Bourdon [38], the $\mathrm{CCV}$ is defined as:

$$
\mathrm{CCV}=\mathrm{CV} \sqrt{\left(1-R^{2}\right)}
$$

where $R^{2}$ is the coefficient of determination obtained from the simple linear regression of the price series on time $(t)$ using the same period for which the CV is estimated. That is, $R^{2}$ is the coefficient of determination of the time trend regression model [45]:

$$
\log (P)=a+\beta t+\varepsilon \quad \text { where } t=1,2, \ldots T
$$

where $a$ is the constant, $\beta$ the slope, $\mathcal{E}$ the disturbance term and $T$ denotes the endpoint of the estimation period. Ordinary least square (OLS) can be applied to estimate Eq. (6).

The difference between the CCVs of the price series for the policy-on and policy-off period can be tested by using the approaches developed by Deb and Pramanik [47] and Singh and Byerlee [48] which are based on Kendal and Stewart [49]. In particular, $\mathrm{Z}$ is defined as [50]: 


$$
Z=\left(\mathrm{CCV}_{1}-\mathrm{CCV}_{2}\right) / D
$$

where D is:

$$
D=\operatorname{CCV}\left\{\left[\left(1+2 \mathrm{CCV}^{2}\right) / 2\right]\left(1 / n_{1}+1 / n_{2}\right)\right\}^{0.5}
$$

where $\mathrm{CCV}_{1}$ and $\mathrm{CCV}_{2}$ relate to periods 1 (policy-off) and 2 (policy-off), respectively; CCV is the CCV for the parent population, that is, the series involving both the policy-off and policy-on periods; $n_{1}$ and $n_{2}$ are the numbers of observations for period 1 and period 2, respectively. Deb et al. [50] showed that $\mathrm{Z}$ follows a standard normal distribution. As in the case of $\mathrm{CV}$, we apply a two-sided test.

In the application below, we apply both the CCV to the non-stationary data and the CV to the detrend data.

\section{Empirical results}

We analyze real monthly wholesale prices of maize and rice reported by the Ministry of Food and Agriculture of Ghana from three major cereal markets. These markets are Techiman and Tamale where the stabilization policy has been implemented, and Ho where this is not the case. The data cover the period January 2006-April 2015 giving a total of 112 data points. For Techiman and Tamale, the period from January 2006-2010 is the pre-buffer stock operation (policy-off) era and the period January 2011-April 2015 the buffer stock era (policy-on). For the entire period January 2006-April 2015, there are no missing observations. The data are presented in Figs. 1, 2, 3, 4, 5 and 6. For each series, we present two graphs: graphs $a$ (at the left-hand side) show the (non-stationary) nominal level data and graphs $b$ (at the right-hand side) the (stationary) data after log differencing.
The results of the augmented Dicky-Fuller (ADF) test are presented in Table 1.

The results of the $\mathrm{ADF}$ unit root test are presented in Table 1. The results indicate that the raw (level) data for all the price series for both maize and rice are non-stationary. After first differencing, all the series are stationary ( $1 \%$ level).

We first compare the policy-on and policy-off periods and markets by way of the CV for the differenced time (stationary) series (see section on methods). The between periods-within markets CVs are presented in Table 2 and the corresponding one-tailed test results in Table 3. Table 4 presents the test results for the policy-on periods between markets. Comparisons by way of the CCV for the raw data are presented in Tables 5 and 6.

The results presented in Tables 2 and 3 indicate that the between period price volatility in the Techiman and Tamale markets declined for both commodities. For instance, in the Techiman market, the CV of the price of maize declined from $22.10 \%$ in period $1,15.01 \%$ in period 2 , and of rice from 16.77 to 4.97 . For the Ho market, the between period CVs of both commodities also declined, though marginally only: of maize from 20.93 to 19.05 and of rice from 12.58 to 12.0 .

The outcomes of the test results presented in Table 3 support the results in Table 2. The changes in the CVs of maize in Techiman and Tamale, and of rice in Tamale are significant at $1 \%$, and that of rice in Techiman at $5 \%$. The changes in the CVs of both commodities in the Ho market are insignificant. This means that in the Ho market, the volatility has not changed between the two periods. Comparison of the effects for the two crops in the Techiman market shows that the policy had a greater effect on the price volatility of rice (11.80) than on maize price
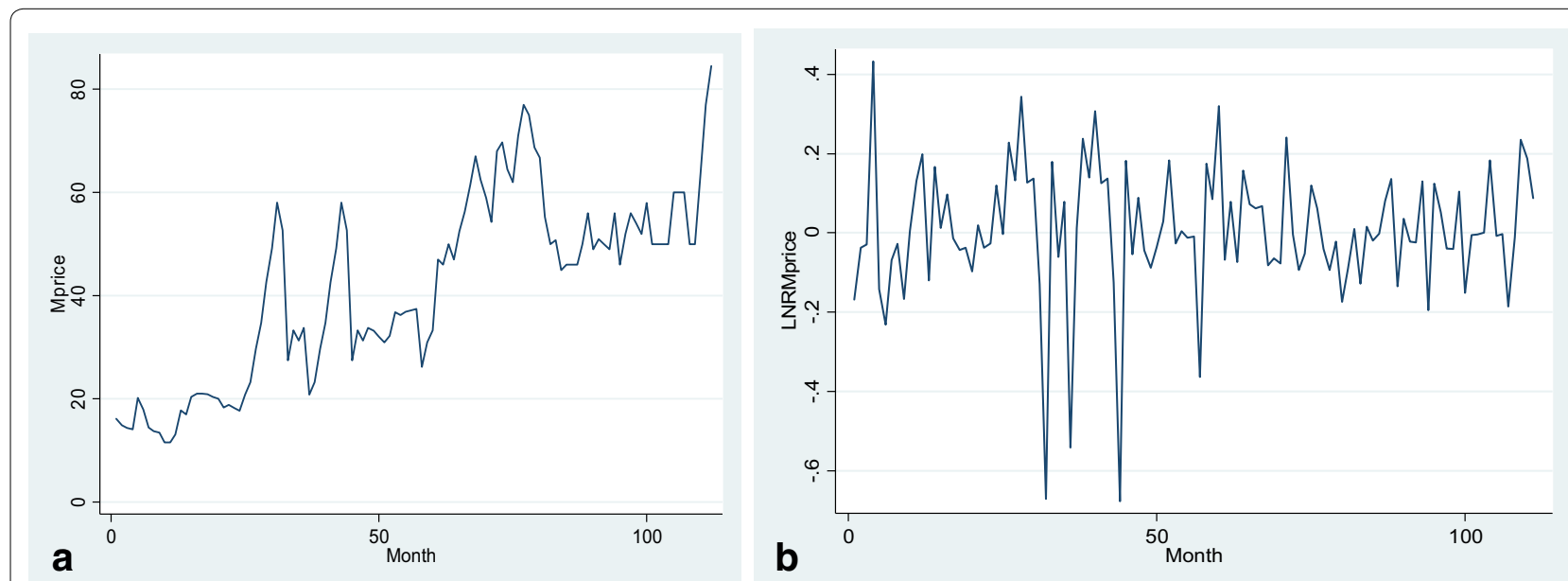

Fig. 1 a, b Price of Maize from January 2006-April 2015 in Techiman market 

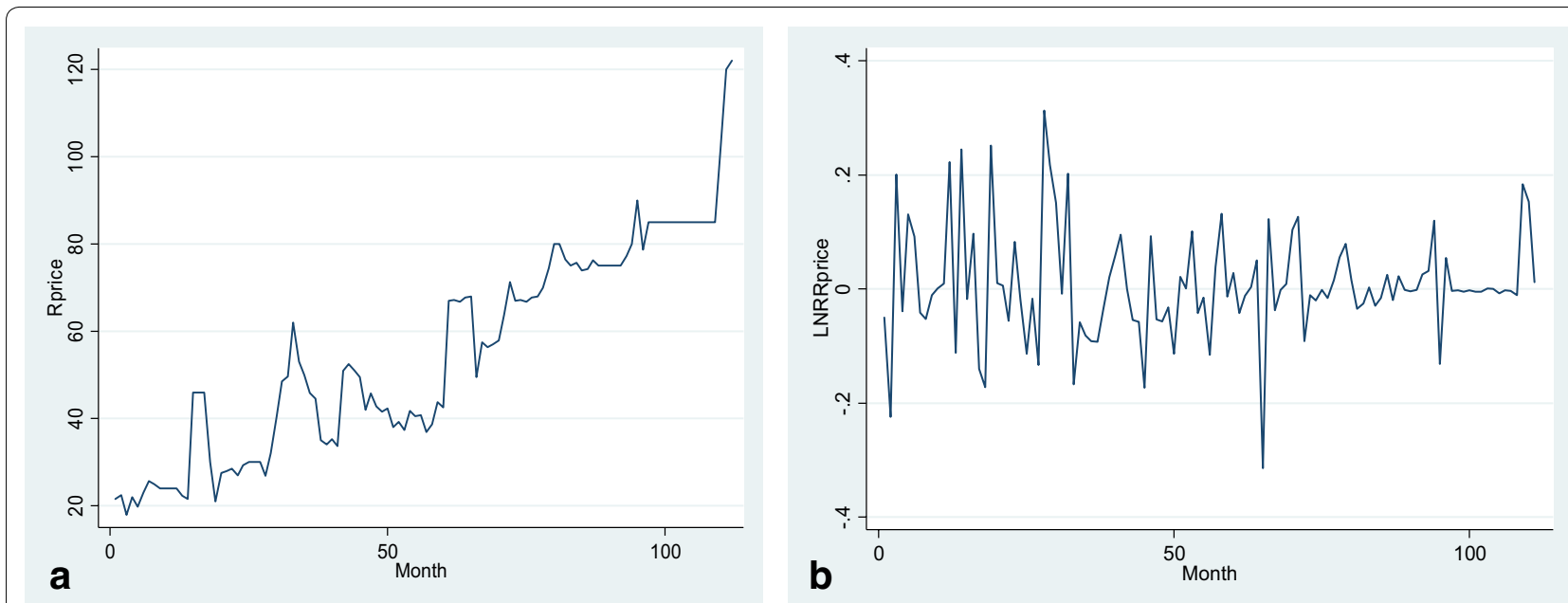

Fig. 2 a, b Price of Rice for January 2006-April 2015 in Techiman market
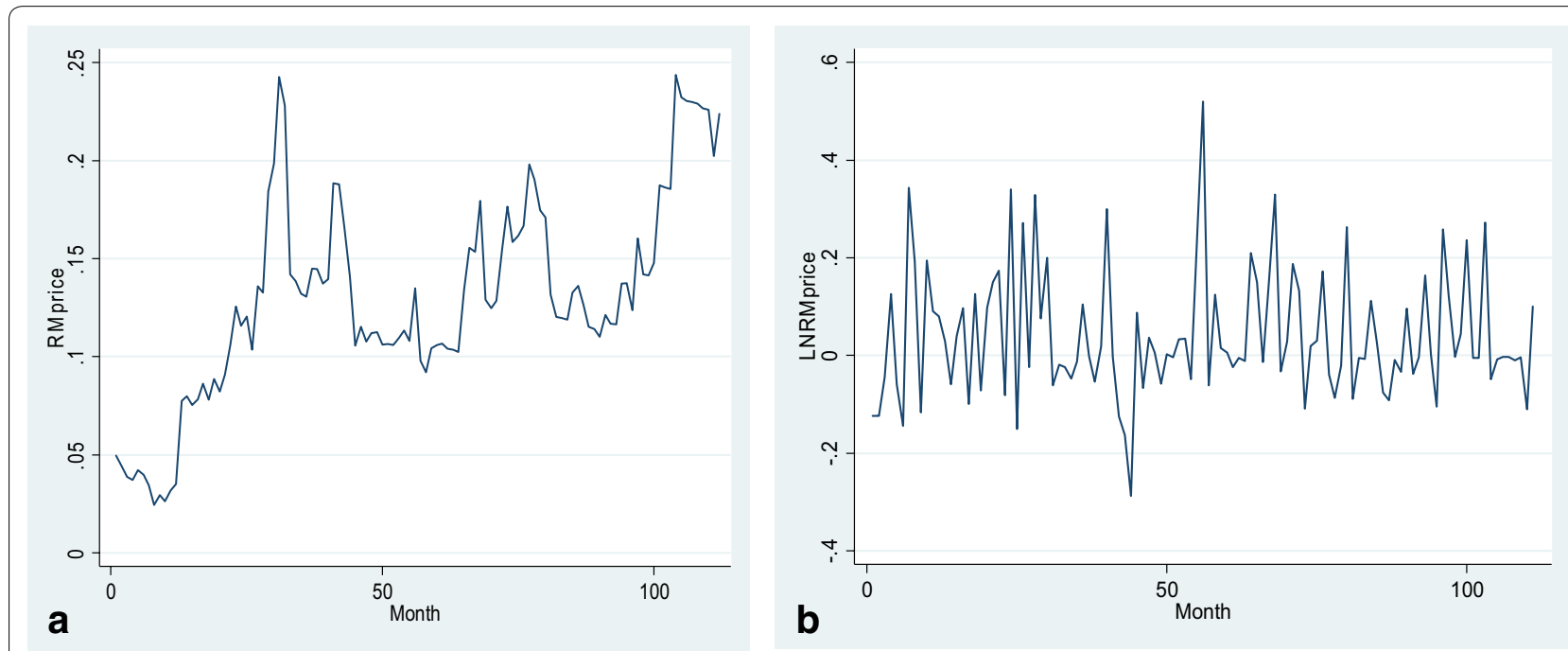

Fig. 3 a, b Price of Maize for January 2006-April 2015 in Tamale market

volatility (7.02). For the Tamale market, the difference is smaller.

Table 4 confirms the policy effects found in Tables 2 and 3. For both commodities, the differences in CVs between the Techiman and Tamale markets on the one hand and of the Ho market on the other are significant at $1 \%$, except for maize between Techiman and Ho where it is significant at $5 \%$.

The results of the CCV analyses presented in Tables 5 and 6 are globally in line with the results of $\mathrm{CV}$ analyses in Tables 2, 3 and 4. Table 6 shows that there is a significant ( $1 \%$ level) difference in the CCV between the policyon and policy-off for both crops in the Techiman market. For the Tamale market, the difference is significant (5\%) for maize and marginally significant for rice. For the Ho market, the differences are insignificant. (Note that the time regression model (6) which is only needed for the $R^{2}$ in the CVV, is presented in "Appendix 1").

\section{Discussion}

Overall, the study provides evidence that the buffer stock policy and dual pricing system have had mitigating effects on the price volatility of maize and rice. For both produces, we estimated the correlation coefficients $(\mathrm{CV})$ based on the detrended time series and the corrected correlation coefficients (CCV) estimated on the raw data. For the Techiman market, the differences between the policy-on and the policy-off periods for both rice and 


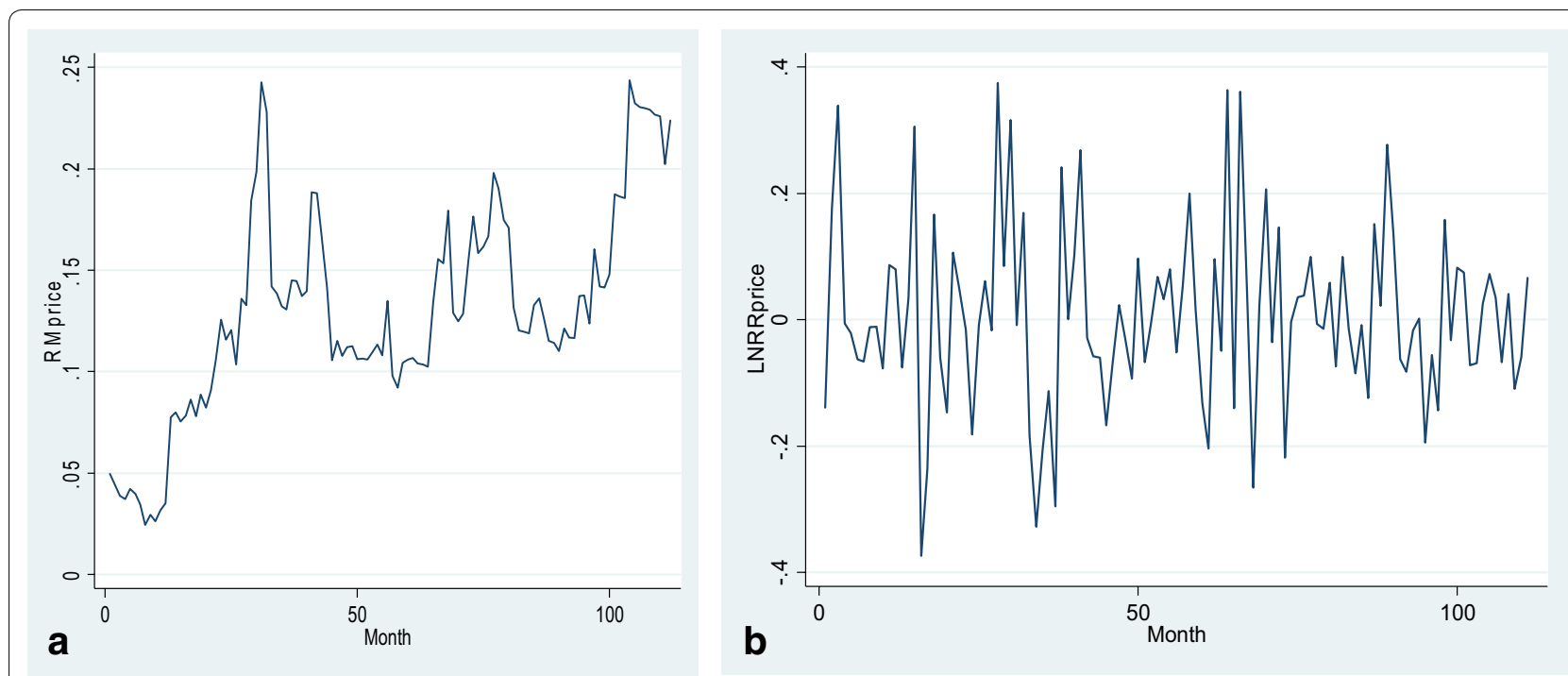

Fig. 4 a, b Price of Rice for January 2006-April 2015 in Tamale market
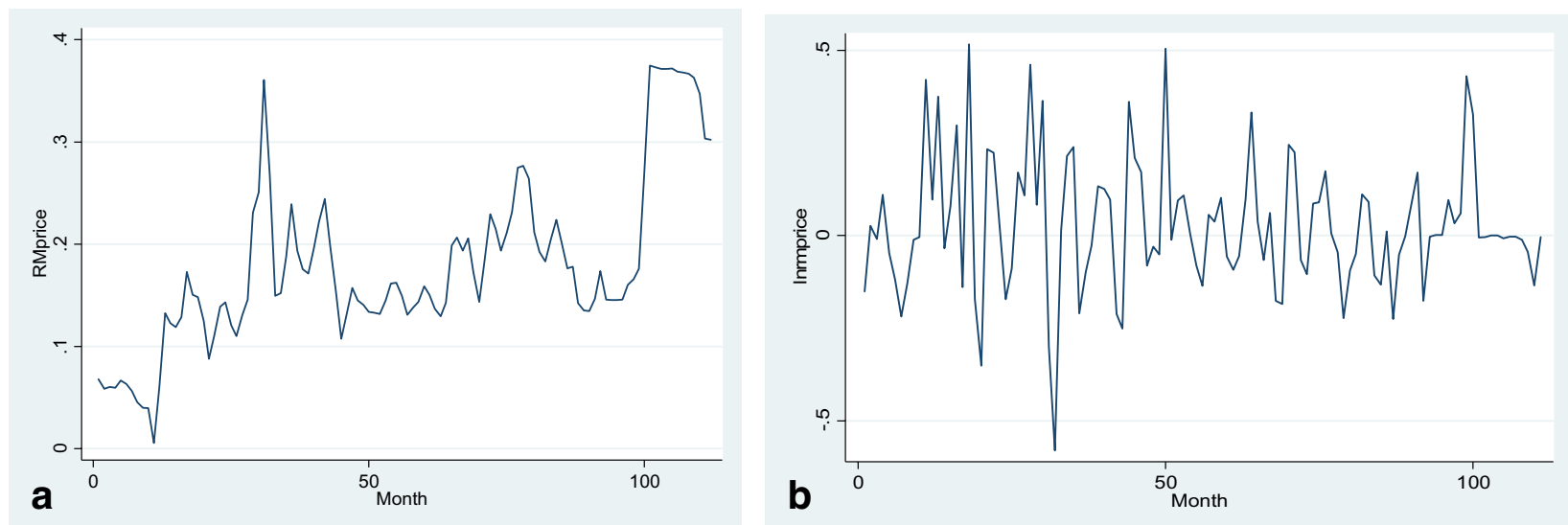

Fig. 5 a, b Price of Maize for January 2006-April 2015 in Ho market
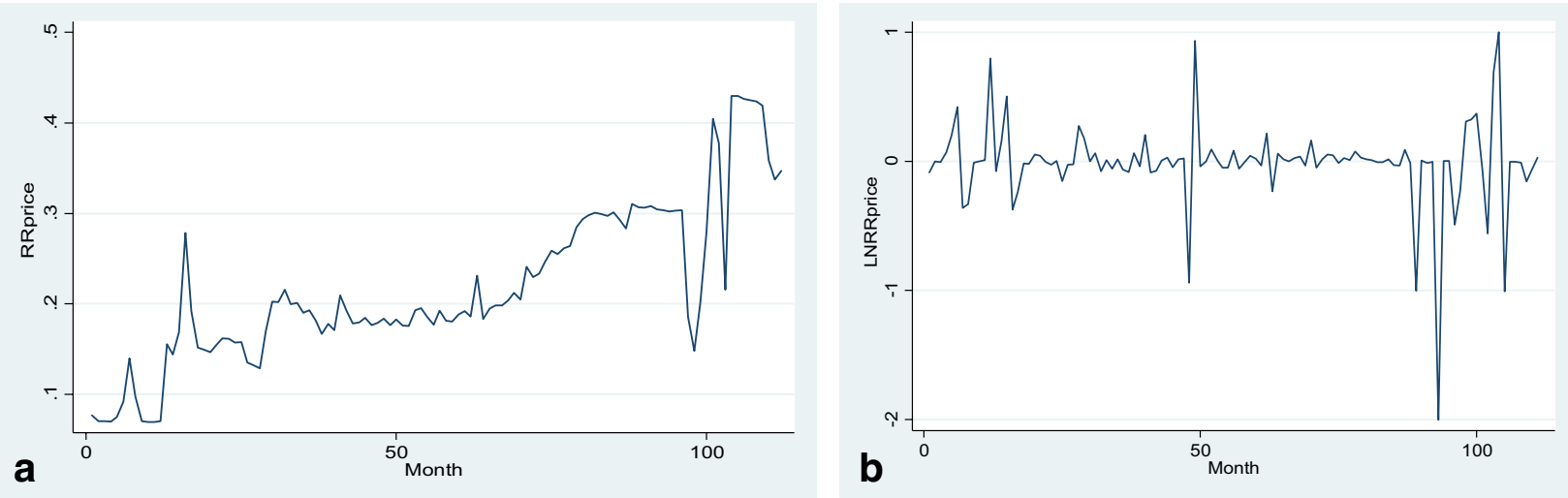

Fig. 6 a, b Price of Rice for January 2006-April 2015 in Ho market 
Table 1 Results of the ADF test

\begin{tabular}{llll}
\hline Market & Price series & \multicolumn{2}{l}{ ADF test } \\
\cline { 3 - 4 } & & Levels & First difference \\
\hline Techiman & Maize & -2.357 & $-5.005^{*}$ \\
& Rice & -1.869 & $-4.844^{*}$ \\
Tamale & Maize & -2.380 & $-4.379^{*}$ \\
& Rice & -2.189 & $-5.988^{*}$ \\
Ho & Maize & -2.344 & $-4.394^{*}$ \\
& Rice & -1.485 & $-4.200^{*}$ \\
\hline
\end{tabular}

Asymptotic critical values for unit root $\mathrm{t}$ test with linear time trend, 12 lags: 10\%: $-2.58 ; 1 \%$ : -3.51 (Banerjee et al. [33])

*Significant at 1\%. A $t$ statistic larger than the critical value implies rejection of $\mathrm{H}_{0}$ and presence of a unit root

maize were found to be significant at $1 \%$ (in both the $\mathrm{CV}$ and CCV test). For the Tamale market, the difference between both periods for maize was significant at $1 \%$, for rice at 5\% (CV test); for maize, the difference was significant at 5\%, for rice at slightly less than $15 \%$ (CCV test). Apparently, the CCV test based on raw data is less conclusive than the CV test based on detrended data. Similar results were found by [44, 46]. For the Ho market without buffer stocking, we failed to reject the hypothesis of no difference between periods 1 and 2 for both rice and maize (both CV and CCV tests). We also compared the Techiman and Tamale markets on the one hand and the Ho market on the other for period 2 for both commodities. The hypotheses of no difference between the policyon and the policy-off markets for both produces were rejected for both types of markets at $1 \%$ (both tests).

The results of the $\mathrm{CV}$ estimates provide evidence that the effect of the policy has generally been greater on rice than on maize as indicated by the higher $\mathrm{CV}$ changes for rice. Table 3 shows that the $\mathrm{CV}$ changes for maize and rice are 7.09 and $11.80 \%$ in the Techiman market, respectively, and 13.19 and $15.18 \%$ in the Tamale market. The average proportions of maize and rice that enter the buffer stocks yearly are estimated at 7.2 and $12.5 \%$, respectively [26]. With these proportions, the buffer stock operations are able to affect the supply and price of rice more than those of maize.

Table 3 furthermore indicates that that the policy has affected the price volatility of both crops in Tamale (CV change for rice: $15.18 \%$, for maize: $13.19 \%$ ) more than in Techiman where the corresponding percentages are 7.09 and 11.80. The differential policy effects between Tamale (Northern Region) and Techiman (Brong Ahaho Region) could have been affected by the fact that Techiman is centrally located in the country with relatively better roads to the farming communities compared to Tamale which is located in the northern part of the country with more remote farming communities. Due to its better infrastructure and location, imports of both produces can reach the Techiman market more easily than the Tamale market which reduces the effects of buffer stocking in the former. Furthermore, the agro-ecological conditions are more favorable in Techiman than in Tamale for the production of both commodities, especially maize [51]. This means that production volumes in Tamale are subject to more fluctuations than in Techiman with, ceteris paribus, larger policy impacts in the former.

Table 3 One-sided tests of $\mathrm{CV}_{1}>\mathrm{CV}_{2}$ : between periodswithin markets

\begin{tabular}{lllllc}
\hline Market & Crop & $\begin{array}{l}\text { Policy- } \\
\text { off period } \\
\text { CV }\end{array}$ & $\begin{array}{l}\text { Policy-on } \\
\text { period } \\
\text { CV }\end{array}$ & $\begin{array}{l}\text { Change } \\
\text { in CV }\end{array}$ & Z-statistics \\
\hline Techiman & Maize & 22.10 & 15.01 & 7.09 & $5.220^{* *}$ \\
Techiman & Rice & 16.77 & 4.97 & 11.80 & $9.172^{* *}$ \\
Tamale & Maize & 19.47 & 6.28 & 13.19 & $11.488^{* *}$ \\
Tamale & Rice & 22.61 & 7.43 & 15.18 & $4.810^{*}$ \\
Ho & Maize & 20.93 & 19.05 & 1.88 & 0.114 \\
Ho & Rice & 12.58 & 12.20 & 0.38 & 0.025 \\
\hline
\end{tabular}

**Significant at $1 \%$; $*$ Significant at $5 \%$

Table 2 Coefficients of variation (CV): between periods-within markets

\begin{tabular}{|c|c|c|c|c|c|c|c|}
\hline \multirow[t]{2}{*}{ Period } & \multirow{2}{*}{$\begin{array}{l}\text { Market } \\
\text { Crop }\end{array}$} & \multicolumn{2}{|c|}{ Techiman market } & \multicolumn{2}{|c|}{ Tamale market } & \multicolumn{2}{|c|}{ Ho market* } \\
\hline & & Maize & Rice & Maize & Rice & Maize & Rice \\
\hline \multirow[t]{3}{*}{ Policy-off period } & Mean & 0.290 & 0.355 & 0.258 & 0.339 & 0.434 & 0.542 \\
\hline & SD & 6.404 & 5.952 & 5.032 & 7.664 & 9.076 & 6.822 \\
\hline & CV $(\%)$ & 22.10 & 16.77 & 19.47 & 22.61 & 20.93 & 12.58 \\
\hline \multirow[t]{3}{*}{ Policy-on period } & Mean & 0.373 & 1.078 & 1.231 & 3.118 & 0.698 & 1.725 \\
\hline & SD & 5.591 & 5.355 & 7.728 & 23.149 & 13.297 & 21.046 \\
\hline & CV (\%) & 15.01 & 4.97 & 6.28 & 7.43 & 19.05 & 12.20 \\
\hline
\end{tabular}

The number of observations for the policy-off period is 59 and for the policy-on period 51

*For the Ho market, the first and second periods are not distinguished by policy intervention 
Table 4 One-sided CV tests between markets (policy-on periods only)

\begin{tabular}{llllll}
\hline Crop & Techiman & Tamale & Ho & Difference & Z-Statistics \\
\hline Maize & 15.01 & 6.28 & - & 8.73 & $5.216^{* *}$ \\
& 15.01 & - & 19.05 & 4.04 & $1.690^{*}$ \\
& - & 6.28 & 19.05 & 12.77 & $5.689^{* *}$ \\
Rice & 4.79 & 7.43 & - & 2.64 & 0.535 \\
& 4.79 & - & 12.20 & 7.41 & $5.195^{* *}$ \\
& & 7.43 & 12.20 & 4.77 & $2.811^{* *}$ \\
\hline
\end{tabular}

Our result is in line with Bryan's [52] analysis of price volatility in 14 countries following the 2008 food crisis. For instance, the Ethiopian government released its grain stocks directly to consumers through consumers' associations organized at local levels to help mitigate the effects of the rising food prices at the time. Although the quantity was not sufficient to reduce overall domestic price levels in the entire country, the release significantly lowered local prices in several parts of the country, thus reducing price volatility.
The results are also in line with the findings of David et al. [13] who used the CV approach for food price volatility analysis. The authors found a negative relationship between locally traded volumes of locally produced crops and the volatility of food prices in some a few Eastern African countries such as Kenya, Malawi, Zambia, and Zimbabwe using strategies such as public buffer stock holdings and management. The results imply that countries that have created an economic environment that allows for rapid supply responses to demand tend to be successful in reducing price volatility of staple food crops. The results corroborate the findings of Abbott [53] who reported that after the 2008 food crisis, buffer stock operations that were introduced by countries in Sub-Saharan Africa have helped to reduce the volatility of some staple food crops, especially cereals.

However, the study by Minot [8] raises questions about the effectiveness of food price stabilization programs like buffer stock operations being implemented by large stateowned enterprises in sub-Sahara African countries like Zambia and Zimbabwe, especially for maize. In spite of the operations, price volatility of maize was significantly higher in some of these countries than in other African

Table 5 Corrected coefficients of variation (CCV) of raw data: between periods-within markets

\begin{tabular}{|c|c|c|c|c|c|c|c|}
\hline & \multirow{2}{*}{$\begin{array}{l}\text { Market } \\
\text { Crop }\end{array}$} & \multicolumn{2}{|c|}{ Techiman market } & \multicolumn{2}{|c|}{ Tamale market } & \multicolumn{2}{|c|}{ Ho market } \\
\hline & & Maize & Rice & Maize & Rice & Maize & Rice \\
\hline \multirow{5}{*}{$\begin{array}{l}\text { Policy-off period (January } \\
\text { 2006-December 2010) }\end{array}$} & Constant & 14.322 & 23.430 & 15.522 & 20.003 & 22.246 & 29.44 \\
\hline & Coefficient & 0.451 & 0.404 & 0.506 & 0.319 & 0.599 & 0.576 \\
\hline & S.E & 0.067 & 0.060 & 0.067 & 0.060 & 0.088 & 0.051 \\
\hline & $R^{2}$ & 0.435 & 0.438 & 0.497 & 0.326 & 0.442 & 0.686 \\
\hline & CCV & 0.319 & 0.223 & 0.287 & 0.269 & 0.290 & 0.145 \\
\hline \multirow{5}{*}{$\begin{array}{l}\text { Policy-on (January } 2011 \text { - } \\
\text { April 2015) }\end{array}$} & Constant & 57.856 & 57.192 & 39.593 & 19.224 & 46.290 & 65.962 \\
\hline & Coefficient & -0.066 & 0.740 & 0.921 & 0.255 & 1.734 & 1.908 \\
\hline & S.E & 0.077 & 0.068 & 0.131 & 0.252 & 0.260 & 0.206 \\
\hline & $R^{2}$ & 0.014 & 0.703 & 0.499 & 0.672 & 0.472 & 0.632 \\
\hline & $\mathrm{CCV}$ & 0.148 & 0.095 & 0.219 & 0.311 & 0.302 & 0.189 \\
\hline
\end{tabular}

** Significant at $1 \%$; ${ }^{*}$ Significant at $5 \%$

Table 6 One-sided tests of $\mathrm{CCV}_{1}>\mathrm{CCV}_{2}$ of raw data: between periods-within markets

\begin{tabular}{lllllll}
\hline Market & Crop & Policy-off CCV & Policy-on CCV & Change in CCV & Z-statistics & P value \\
\hline Techiman & Maize & 0.319 & 0.148 & 0.171 & $5.191^{* *}$ & 0.000 \\
Techiman & Rice & 0.223 & 0.095 & 0.128 & $5.863^{* *}$ & 0.000 \\
Tamale & Maize & 0.287 & 0.219 & 0.068 & $1.889^{*}$ & 0.029 \\
Tamale & Rice & 0.269 & 0.311 & 0.042 & 1.520 & 0.064 \\
Ho & Maize & 0.290 & 0.302 & 0.012 & 0.279 & 0.780 \\
Ho & Rice & 0.145 & 0.168 & 0.023 & 1.071 & 0.285 \\
\hline
\end{tabular}

** Significant at $1 \%$; ${ }^{*}$ Significant at $5 \%$ 
countries with little or no price stabilization programs or policies for maize. This could be because the former countries had inherently more unstable food markets [8].

\section{Conclusion}

The objective of this paper was to analyze the effects of buffer stock operations on the price volatility of maize and rice in some selected markets in Ghana. Based on times series data obtained from the Ministry of Food and Agriculture spanning the period from January 2006 to April 2015, we employed the (corrected) coefficient of variation as measures of volatility. The results show that price volatility of maize and rice was stabilized in the markets where the output price stabilization policy was implemented. For the same crops, price volatility was persistent in a market where the policy was absent. With these findings, we conclude that the buffer stock operations have been quite successful to control the price volatility of maize and rice. The findings of this study provide an appeal for scaling up of the policy to other parts of the country, especially remote areas, where maize and rice production are intensive, yet access to these areas by buyers are challenging.

A crucial condition for the policy to be effective is the proportion of the production volume that enters into buffer stock. Too small a proportion renders the policy ineffective. Benin et al. [26] argued that the proportion is critical for the policy to be effective and sustainable. As a rule of thumb, the authors recommend about $27 \%$ for Ghana.

An important side effect of the buffer stock operations is that they provide traders, individual farmers and their organizations with secure, and reliable storage which is crucial for the quality and price of the produce sold when prices are high. Moreover, reliable and safe storage provides farmers with credible title to their produce which enables them to obtain credit for their activities from the government but also from the private sector [5456]. Reliable storage creates a warehouse receipt system (WRS) that enables smallholder farmers to access credit due to improved security for loan recovery.

The study also highlights the importance of buffer stocks as a tool for implementing crop insurance programs [57], especially with the involvement of the private sector. To hedge farmers against the risks posed by adverse weather conditions, destruction by pests such as armyworms and disease outbreaks which have the potential to cause farmers huge losses, weather indexbased crop insurance programs may be facilitated with buffer stock providing storage systems. If farmers have access to market based-insurance tools, variations in the production and prices may not require immediate policy response by government unless characterized by catastrophic events. Moreover, with the involvement of the private sector, farmers will have different packages of insurance programs to choose from to minimize risk. It is expected that with stable output prices, the income of farmers will improve and stimulate smallholder farmers to invest into increasing their farm outputs [58].

Finally, the results of the study lend insight into directions for future research, particularly to find out the extent to which the gains made through the stabilizations of prices of maize and rice affect the welfare of the smallholder farmers and their families including their health. It is after this that more comprehensive conclusions can be drawn on the real impacts of the policy-on smallholder farming in Ghana.

\section{Abbreviations \\ BULOG: Bandan Urusan Logistik; CACP: Commission for Agricultural Costs and Prices; CCV: Corrected coefficient of variation; CV: Coefficient of variation; DOLOG: Depot Logistics; FAO: Food and Agriculture Organization; FRA: Food Reserve Agency; HLPE: High-Level Panel of Experts; LBC: Licensed Buying Agents; MoFA: Ministry of Food and Agriculture; NAFCO: National Buffer Stock Company.}

\section{Authors' contributions}

This paper was conceived and developed by EA with significant guidelines and intellectual contributions from HF and KFA. All authors read and approved the final manuscript.

\section{Author details \\ ${ }^{1}$ GIMPA Consultancy, Training and Innovation Directorate (GCTID), Ghana Institute of Management and Public Administration, Accra, Ghana. ${ }^{2}$ Depart- ment of Economic Geography, Faculty of Spatial Sciences, University of Groningen, Landleven 1, 9747 AD Groningen, The Netherlands. ${ }^{3}$ College of Economics and Management, Northwest Agriculture and Forestry Univer- sity, Yangling, China.}

\section{Acknowledgements}

We are grateful to the Statistical, Research and Information Division (SRID) of the Ministry of Food and Agriculture, Ghana, for providing data for this study.

\section{Competing interests}

The authors declare that they have no competing interests.

\section{Availability of data and materials}

The data that support the findings of this study are available from the Statistical, Research and Information Division (SRID) of the Ministry of Food and Agriculture, Ghana. Data are, however, available from the authors upon reasonable request.

Consent for publication

Not applicable.

Ethics approval and consent to participate Not applicable.

Funding

Not applicable.

\section{Appendix 1}

See Table 7. 
Table 7 The regressions underlying the CCV calculations

\begin{tabular}{|c|c|c|c|c|}
\hline Market & Crop & Constant & Coeff. & $R^{2}$ \\
\hline \multicolumn{5}{|c|}{ Policy-off period } \\
\hline \multirow[t]{4}{*}{ Techiman } & Maize & $14.322^{* * *}$ & $0.451^{* * *}$ & 0.435 \\
\hline & & $(2.366)$ & $(0.067)$ & \\
\hline & Rice & $23.430^{* * *}$ & $0.404^{* * *}$ & 0.438 \\
\hline & & $(2.106)$ & $(0.060)$ & \\
\hline \multirow[t]{4}{*}{ Tamale } & Maize & $15.522^{* * *}$ & $0.506^{* * *}$ & 0.497 \\
\hline & & $(2.342)$ & $(0.067)$ & \\
\hline & Rice & $20.003^{* * *}$ & $0.319^{* * *}$ & 0.326 \\
\hline & & $(2.111)$ & $(0.060)$ & \\
\hline \multirow[t]{4}{*}{ Ho } & Maize & $22.246^{* * *}$ & $0.599 * * *$ & 0.442 \\
\hline & & $(3.079)$ & $(0.088)$ & \\
\hline & Rice & $29.440^{* * *}$ & $0.576^{* * *}$ & 0.686 \\
\hline & & $(1.794)$ & $(0.051)$ & \\
\hline \multicolumn{5}{|c|}{ Policy-on period } \\
\hline \multirow[t]{4}{*}{ Techiman } & Maize & $57.856^{* * *}$ & $-0.066^{* * *}$ & 0.014 \\
\hline & & $(2.360)$ & $(0.077)$ & \\
\hline & Rice & $57.192^{* * *}$ & $0.740^{* * *}$ & 0.703 \\
\hline & & $(2.071)$ & $(0.068)$ & \\
\hline \multirow[t]{4}{*}{ Tamale } & Maize & $39.593^{* * *}$ & $0.921^{* * *}$ & 0.499 \\
\hline & & (3.976) & $(0.131)$ & \\
\hline & Rice & $19.224^{* *}$ & $2.555^{* * *}$ & 0.672 \\
\hline & & (7.698) & $(0.252)$ & \\
\hline \multirow[t]{4}{*}{ Ho } & Maize & $49.206^{* * *}$ & $1.734^{* * *}$ & 0.472 \\
\hline & & $(8.083)$ & $(0.260)$ & \\
\hline & Rice & $65.926^{* * *}$ & $1.908^{* * *}$ & 0.632 \\
\hline & & $(6.267)$ & $(0.206)$ & \\
\hline
\end{tabular}

Price series as the dependent variable and time trend as the independent variable

\section{Publisher's Note}

Springer Nature remains neutral with regard to jurisdictional claims in published maps and institutional affiliations.

Received: 18 July 2018 Accepted: 24 September 2018 Published online: 01 October 2018

\section{References}

1. FAO. The State of Food Insecurity in the World: How Does International Price Volatility Affect Domestic Economies and Food Security, Rome, Italy. 2011.

2. Meerman J, Aphane J. Impact of high food prices on nutrition. In: Proceedings on expert consultation on policy responses to high and volatile food prices, FAO. Google Scholar. 2012.

3. Arias P, Hallam D, Krivonos E, Morrison J. Smallholder integration in changing food markets. Rome: Food and Agriculture Organization of the United Nations; 2013.

4. Rapallo R. Food price volatility and the right to food, right to food policy brief No. 1, coherent food security responses: incorporating right to food into global and regional food security initiatives, food and agriculture organization, FAO, Rome. 2011.

5. Jayne TS. Managing food price instability in East and Southern Africa. Glob Food Secur. 2012;1(2):143-9.
6. Amikuzuno J, von Cramon-Taubadel S. Seasonal variation in price transmission between tomato markets in Ghana. J Afr Econ. 2012;21(4):669-86.

7. Prakash A. Why volatility matters. In: Prakash A, editor. Safeguarding food security in volatile global markets. Rome: Food and Agriculture Organization of the United Nations; 2011. p. 3-26.

8. Minot N. Food price volatility in Africa: has it really increased? Food Policy. 2014;45:45-56.

9. Sumpsi JM. The volatility of the agricultural markets and the world food crisis. Cuadernos de Estrategia. 2013;161(1):142-69.

10. Byerlee D, Jayne TS, Myers RJ. Managing food price risks and instability in a liberalizing market environment: overview and policy options. Food Policy. 2006;31(4):275-87.

11. Dia Kamgnia B. Political economy of recent global food price shocks: gainers, losers and compensatory mechanism. J Afr Econ. 2011;20((suppl_1)):i142-210.

12. Timmer P. Reflections on food crises past. Food Policy. 2010;35:1-11.

13. David T, Gitau R, Meyer FH, Chisanga B, Jayne TS. Evaluating price volatility and the role of trade in Eastern and Southern African maize markets. In: 2016 AAAE Fifth international conference (No. 249291), Addis Ababa, Ethiopia, 2016.

14. Abbott P, Borot de Battisti A. Recent global food price shocks: causes, consequences and lessons for African governments and donors. J Afr Econ. 2011;1(20(suppl_1)):i12-62.

15. Arezki MR, Bruckner M. Food prices and political instability. IMF working paper no. WP/11/62. International Monetary Fund. 2011.

16. Berazneva J, Lee DR. Explaining the African food riots of 2007-2008: an empirical analysis. Food Policy. 2013;1(39):28-39.

17. Bellemare MF. Rising food prices, food price volatility, and social unrest. Am J Agric Econ. 2015;97(1):1-21.

18. Schneider M. We are hungry! - a summary report of food riots, government responses, and states of democracy in 2008. In: Working paper, Department of Development Sociology, Cornell University: Cornell, 2008.

19. Clapp J. Food price volatility and vulnerability in the global south: considering the global economic context. Third World Q. 2009;30(6):1183-96.

20. Rashid S. Food price stabilization policies in a globalizing world. Case study \#6-8 of the program: food policies for developing countries: the role of Government in the global food system. Corenll University, Ithaca, New York. 2007

21. Sutopo W, Bahagia SN, Cakravastia A, Samadhi TMAA. A buffer stocks model for stabilizing price of staple food with considering the expectation of non-speculative wholesaler. In: Proceedings of the world congress on engineering. (Vol. 3); 2010.

22. Pinstrup-Andersen P. Political economy of food price policy: key policyrelated lessons. In: Pinstrup-Andersen P, editor. Food price policy in an era of market instability: a political economy analysis. 1st ed. Oxford: Oxford University Press; 2015

23. Ackello-Ogutu C. Managing food security implications of food price shocks in Africa. J Afr Econ. 2011;1(20(suppl_1)):i100-41.

24. Sasson A. Food security for Africa: an urgent global challenge. Agric Food Secur. 2012;1(1):2.

25. Nankani G. The challenge of agriculture in Ghana: what is to be done. London: International Growth Center; 2009.

26. Benin S, Johnson ME, Abokyi E, Ahorbo G, Jimah K, Nasser G, Owusu V, Taabazuing J, Tenga A. Revisiting agricultural input and farm support subsidies in Africa: the case of Ghana's mechanization, fertilizer, block farms, and marketing programs. No. 1300. International Food Policy Research Institute (IFPRI); 2013

27. HLPE (High-Level Panel of Experts). Price volatility and food security. A report by the high-level panel of experts on food security and nutrition of the committee on world food security. Rome. 2011.

28. Kharas H. Making Sense of Food Price Volatility. Washington: The Brookings Institution; 2011

29. Hajkowicz S, Negra C, Barnett P, Clark M, Harch B, Keating B. Food price volatility and hunger alleviation-can Cannes work? Agric Food Secur. 2012;1(1):8.

30. Von Braun J, Tadesse G. Global food price volatility and spikes: an overview of costs, causes, and solutions, ZEF-Discussion Papers on Development Policy No. 161, Center for Development Research, Bonn, 2012. 
31. Dickey DA, Fuller WA. Distribution of the estimators for autoregressive time series with a unit root. J Am Stat Assoc. 1979;74(366a):427-31.

32. Cavaliere G, Phillips PC, Smeekes S, Taylor AM. Lag length selection for unit root tests in the presence of nonstationary volatility. Econ Rev. 2015;34(4):512-36.

33. Banerjee A, Dolado J, Galbraith J, Hendry D. Co-integration, error correction, and the econometric analysis of non-stationary data. Oxford: Oxford University Press; 1993.

34. Cheung YW, García Pascual A. Testing for output convergence: a reexamination. Oxf Econ Pap. 2004;56(1):45-63.

35. Yang J, Haigh MS, Leatham DJ. Agricultural liberalization policy and commodity price volatility: a GARCH application. Appl Econ Lett. 2001;8(9):593-8.

36. Balcombe K. The nature and determinants of volatility in agricultura prices: an empirical study. In: Safeguarding food security in volatile global markets. 2011. p. 85-106.

37. Gilbert CL, Morgan CW. Food price volatility. Philosophical Transactions of the Royal Society of London B: Biological Sciences. 2010; 365(1554):3023-34.

38. Huchet-Bourdon M. Agricultural commodity price volatility: an overview, OECD food, agriculture and fisheries papers, No. 52. Paris: OECD Publishing; 2011.

39. Abdi H. Coefficient of variation. Encycl Res Des. 2010;1:169-71.

40. Banik S, Kibria BM, Sharma D. Testing the population coefficient of variation. J Mod Appl Stat Methods. 2012;11(2):325-35.

41. Bhoj DS, Ahsanullah M. Testing equality of coefficients of variation of two populations. Biom J. 1993;35(3):355-9.

42. O'Connor DM. Kean empirical issues relating to dairy commodity price volatility. In: Piot-Lepetit I, M'Barek R, editors. Methods to analyse agricultural price volatility. New York: Springer; 2011.

43. Ali S, Jabbar A. Growth and variability in area production and yield of selected fruit crops in Khyber Pakhtunkhwa. Pak J Agric Res. 2015;28(1):64-9.

44. Cuddy JD, Valle PD. Measuring the instability of time series data. Oxford Bull Econ Stat. 1978;40(1):79-85.

45. Krishan B, Chanchal A. Agricultural growth and instability in western Himalayan region: an analysis of Himachal Pradesh. India. J. Agric. Life Sci. 2014;1(1):21-7.
46. Badiane O, Odjo S. Regional trade and volatility in staple food markets in Africa. In: Kalkuhl M, von Braun J, Torero M, editors. Food price volatility and its implications for food security and policy 2016. Cham: Springer; 2016. p. 385-412.

47. Deb U, Soumitra P. Groundnut production performance in Bangladesh: a district level analysis. Econ Aff. 2015;60(03):391-400.

48. Singh AJ, Byerlee D. Relative variability in wheat yields across countries and over time. J Agric Econ. 1990;41(1):21-32.

49. Kendall M, Stuart A. The advanced theory of statistics. Vol. 1: distribution theory. London: Griffin, 4th ed. 1977.

50. Deb UK, Joshi PK, Bantilan MC. Impact of modern cultivars on growth and relative variability in sorghum yields in India. Agric Econ Res Rev. 1999;12(2):84-106.

51. MoFA. Agriculture in Ghana, Facts and figures for 2015, Statistics, research and information directorate (SRID) Ministry of food and agriculture, Accra, Ghana, 2016.

52. Bryan SA. Cacophony of policy responses: evidence from fourteen countries during the 2007-2008 food crisis. In: Pinstrup-Andersen P, editor. Food price policy in an era of market instability: a political economy analysis. Oxford: Oxford University Press; 2013.

53. Abbott P. Stabilisation policies in developing countries after the 2007-2008 food crisis. Agric Polic Poverty Reduct. 2012;2:109-68.

54. Demeke M, Dawe D, Tefft J, Ferede T, Bell W. Stabilizing price incentives for staple grain producers in the context of broader agricultural policies. Debates and Country Experiences. 12-05 Sept 2012.

55. FAO, IFAD, IMF, OECD, UNCTAD, WFP, the World Bank, the WTO, IFPRI and the UN HLTF. Price volatility in food and agricultural markets: policy responses. Rome, 2011.

56. Katunze M, Kuteesa A, Mijumbi T, Mahebe D. Uganda warehousing receipt system: improving market performance and productivity. Afr Dev Rev. 2017:29(S2):135-46.

57. Varangis $P$, Anderson JR. Agricultural markets and risks: management of the latter, not the former. The World Bank. 2002.

58. Eriksen S, Lensink R. Measuring the impact of an ongoing microcredit project: evidence from a study in Ghana. J Dev Eff. 2015;7(4):519-29.
Ready to submit your research? Choose BMC and benefit from:

- fast, convenient online submission

- thorough peer review by experienced researchers in your field

- rapid publication on acceptance

- support for research data, including large and complex data types

- gold Open Access which fosters wider collaboration and increased citations

- maximum visibility for your research: over $100 \mathrm{M}$ website views per year

At $\mathrm{BMC}$, research is always in progress.

Learn more biomedcentral.com/submissions 